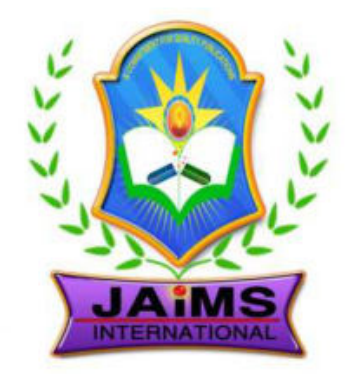

ISSN 2456-3110

Vol $4 \cdot$ Issue 6

Nov-Dec 2019

Journal of

Ayurveda and Integrated Medical Sciences

www.jaims.in

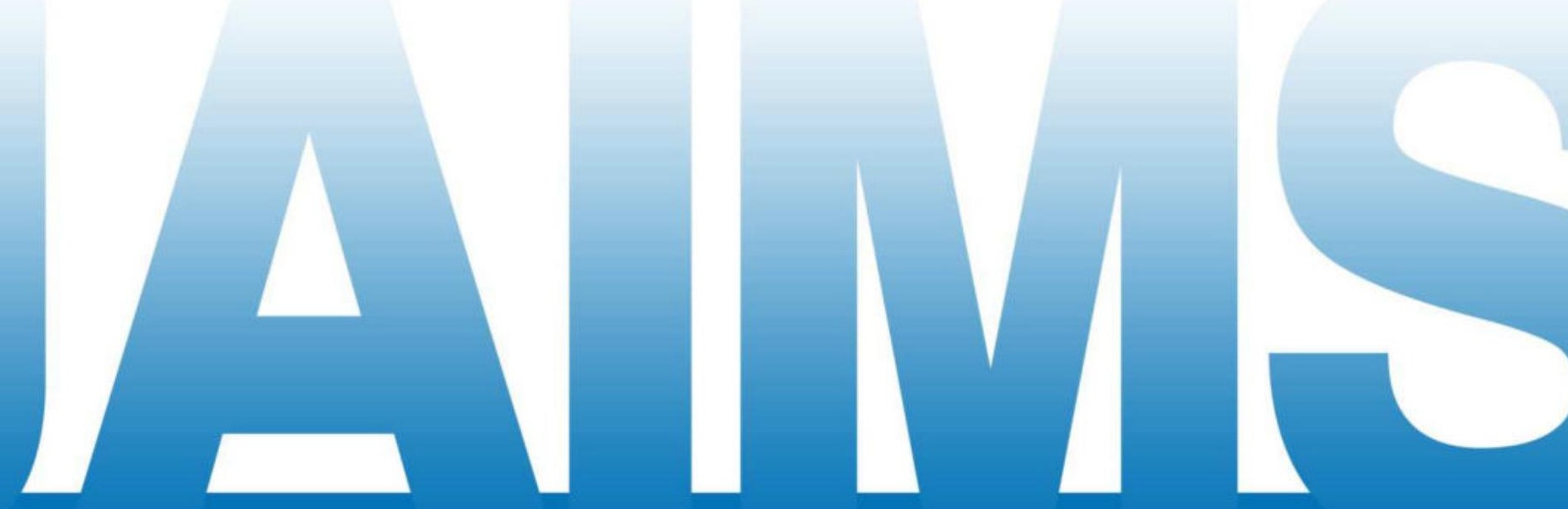

An International Journal for Researches in Ayurveda and Allied Sciences

Charaka

Publications 


\section{A physiological study of Bhrajaka Pitta and clinical view of Shwitra Kusthari Rasa and Shashilekha Vati in Shwitra Roga}

\section{Dr. Nand Kishor Dadhich}

Associate Professor \& Head, Department of Kriya Sharir, Faculty of Ayurved, Main Campus, Uttarakhand Ayurveda University, Dehradun, Uttarakhand, INDIA.

\section{A B S T R A C T}

\begin{abstract}
Background: Ayurveda defines human body as a hospitable homestasis of Dosha, Dhatu and Mala. The equilibrium of Dhatu is health. Any disturbance in their equilibrium leads to disease. In the present scenario, people are very much conscious about their health as well as beautiful and clear skin. Thus health and beauty are two faces of single coin. Moreover a person who is physically healthy and is personified by beauty is much more intelligent and confident them a normal being. Discoloration of skin without perceiving pain is exclusive character of Shwitra (Vitiligo) Roga. Aim: To study the treatment principle in management of Shwitra (vitiligo) according to Ayurveda. Methodology: 60 clinically diagnosed cases of Switra (Vitiligo) were divided into 2 groups and treated with Shwitra Kusthari Rasa 250mg in Group A and Shashilekha Vati $250 \mathrm{mg}$ in Group B. Bakuchi Taila local application on the affected patches was done in both the groups for 90 days. Discussion: Therefore it can be concluded that Shwitra Kusthari Rasa, Shashilekha Vati and Bakuchi Taila both are potent and effective for the management of Shwitra Roga vis-a-vis Vitiligo.
\end{abstract}

Key words: Bhrajaka Pitta, Shwitra Kusthari Rasa, Shashilekha Vati, Bakuchi Taila

\section{INTRODUCTION}

Shwitra (Vitiligo) is one of the most common skin disorder prevalent now a day. Skin is one of most sensitive organ which play a important of in health is as well as beauty. Even a small lession on superficial skin can cause a lot of anxiety and depression in several people. Vitiligo means loss of pigment with white patches of varied sizes often symmetrically distributed. The skin bodering the affected sites is

\section{Address for correspondence:}

\section{Dr. Nand Kishor Dadhich}

Associate Professor \& Head, Department of Kriya Sharir, Faculty of Ayurved, Main Campus, Uttarakhand Ayurveda University,

Dehradun, Uttarakhand, INDIA.

E-mail: dadhichnand@gmail.com

Submission Date: 08/11/2019 Accepted Date: 19/12/2019

\begin{tabular}{|l|l|} 
Submission Date: 08/11/2019 Accepted Date: 19/12/2019 \\
\hline Quick Response Code & Website: www.jaims.in \\
\hline
\end{tabular}

usually hyperpigmented and hair in affected areas is usually but not always white. ${ }^{[1]}$

A lot of references are available in different Ayurvedic classic which shows that the disease was prevalent at those time.

Hence, it is need of the hour to carry researches of finding efficient, economic, natural and safer formulations to manage Shwitra Roga. Keeping this mind the present study was carried out to study basic Ayurvedic principles in its management.

Therefore we decided to study description of this disease and also various formulations for its cure in classical medical literature which is responsible for the normal texture of the skin and check the pathogenesis of Shwitra Roga vis-a-vis vitiligo.

\section{OBJECTIVE OF THE STUDY}

Clinical evaluation of Shwitra Kusthari Rasa, Shashilekha Vati and Bakuchi Taila (Herbomeneral formula) in the management of Shwitra Roga on scientific parameters. 


\section{MATERIALS AND MethodS}

\section{Selection of the Patients}

The study was conducted on 60 clinically diagnosed and confirmed patients of Shwitra Roga (Vitiligo) which were selected from OPD wing of Post Graduates Department of Kriya Sharir, NIA, Jaipur.

Age Group

Patient between the age of 1-60 years were considered for the study

\section{Clinical Evaluation}

A proforma prepared on the basis of description of Shwitra Roga in classical text as well as modern text. All the symptoms, etilogical factors of Shwitra (vitiligo) as described in Ayurvedic and modern dermatology were used for the purpose.

\section{Inclusion Criteria}

- Those who are suffering from disease (white patches within 10 years not beyond the time limit (10 years).

- The patients with classical signs and symptoms of Shwitra and that of Vitiligo were included.

- Patients of both sexes were included.

\section{Exclusive Criteria}

- If the patient white patches are the result of burn, chemical burn, psoriasis were excluded.

- Very weak, suffering from psychological as mental disorder were excluded.

- Patient of other Infection, pregnent women, feeding mother and feeding baby were excluded.

- Generalized Vitiligo or whose complete body become white and in albino.

- Patient of vitiligo associated with malignancy of skin were excluded.

\section{Criteria of Assessment}

On the basis of recoloration or pigmentation the results were screened during and after the treatment.

\section{Subjective improvement}

Any change in their clinical manifestation and growing feeling of well being produced if any after the course of the therapy.

\section{Clinical assessment}

For the clinical assessment the incidence of presenting feature was worked out and the severity of symptoms was rated in each patients.

Following parameters were adopted for statical analysis and preparing the graphical value and data.

- Without improvement or not recoloration

- Repigmentation $(0.01-0.025 \mathrm{~cm}$ of diameter and the patches were upto 5)

- Repigmentation (0.026-0.50 cm of diameter and the patches were 6-10)

- Repigmentation (0.51-0.75 diameter and the patches were 11-15).

- Repigmentation $(0.76-100 \mathrm{~cm}$ diameter and the patches were 16-20).

Clinically features were looked ${ }^{[2-6]}$

3. Iching (kandu)

4. Sweating

5. Pain

6. Secretion

7. Pin point bleeding

8. Colour of skin

9. Surface of affected part

10. Intolerance to heat

11. Hair present or absent

12. Colour of hairs

13. Margins of the lesions

Numbers of lesion

- Before treatment of pigmentation

- After the treatment of the pigmentation 
Size of lesions

1. Maximum

2. Minimum

\section{Laboratory Investigations}

To exclude other systemic illness the lab investigation were done.

- $\mathrm{Hb} \%, \mathrm{TLC}, \mathrm{DLC}, \mathrm{ESR}$.

- Urine test routine and microscopic examination

- Thyroid function test

- Serum copper examination

- Other serological test SGOT, SGPT as per requirements of patient.

Photographic change

Coloured photograph of the lesions were taken before and after the treatment of the patients.

Posology

Group A: 30 clinically diagnosed cases of Shwitra (Vitiligo) were registered in OPD and adviced 250mg tablet Shwitra Kusthari Rasa and local application of Bakuchi Taila.

Group B: 30 clinically diagnosed cases of Shwitra (Vitiligo) were registered in OPD and adviced, Shashilekha Vati $250 \mathrm{mg}$ tablet and local application of Bakuchi Taila.

\section{Dosage}

Tab Shashilekha Vati 250mg and Shwitra Kusthari Roga 250mg in adult patient twice a day before breakfast with Bakuchi Taila 2 drops and half teaspoon of honey. Bakuchi Taila for local application on the affected patches.

Duration of Clinical Trial

90 days

\section{Selection of Drug}

1. Shwitra Kusthri Rasa (tablet) ${ }^{[7]}$

Name of text book - Rasa Ratna Samuchaya (Kustha Rogadikar)
Table 1: Different constituents of Shwitra Kusthri Rasa (tablet)

\begin{tabular}{|l|l|l|l|}
\hline SN & $\begin{array}{l}\text { Name of } \\
\text { Drug }\end{array}$ & $\begin{array}{l}\text { Botanical/English } \\
\text { Name }\end{array}$ & Qty. \\
\hline 1. & $\begin{array}{l}\text { Sudha } \\
\text { Parad }\end{array}$ & Pure mercury & 1 part \\
\hline 2. & $\begin{array}{l}\text { Sudha } \\
\text { Gandhak }\end{array}$ & Pure sulphur & 1 part \\
\hline 3. & $\begin{array}{l}\text { Tamra } \\
\text { Bhasma }\end{array}$ & Copper ash & 1 part \\
\hline 4. & $\begin{array}{l}\text { Tutha } \\
\text { Bhasma }\end{array}$ & $\begin{array}{l}\text { Blue vitriol CuSO } \\
5\end{array}$ & 1 part \\
\hline 5. & $\begin{array}{l}\text { Bakuchi } \\
\text { Seeds }\end{array}$ & $\begin{array}{l}\text { Psoralea } \\
\text { corylifolia }\end{array}$ & $\begin{array}{l}\text { Decoction as per } \\
\text { requirements }\end{array}$ \\
\hline
\end{tabular}

2. Shashilekha Vati ${ }^{[8]}$

Name of text book - Yoga Ratnakar

Table 2: Different constituents of Shashilekha Vati

\begin{tabular}{|l|l|l|l|}
\hline SN & $\begin{array}{l}\text { Name of } \\
\text { Drug }\end{array}$ & $\begin{array}{l}\text { Botanical/English } \\
\text { Name }\end{array}$ & Qty. \\
\hline 1. & $\begin{array}{l}\text { Sudha } \\
\text { Parad }\end{array}$ & Pure mercury & 1 part \\
\hline 2. & $\begin{array}{l}\text { Sudha } \\
\text { Gandhak }\end{array}$ & Pure sulphur & 1 part \\
\hline 3. & $\begin{array}{l}\text { Tamra } \\
\text { Bhasma }\end{array}$ & Copper ash & 1 part \\
\hline 4. & $\begin{array}{l}\text { Bakuchi } \\
\text { seeds }\end{array}$ & Psoralea corylifolia & $\begin{array}{l}\text { Deoction as per } \\
\text { requirements }\end{array}$ \\
\hline
\end{tabular}

\section{Observations and Results}

Overall relief / Improvement in 60 patient of Shwitra Roga (Vitiligo) in all two group after the therapy.

Group - A

\begin{tabular}{|c|c|c|c|c|c|c|c|c|c|}
\hline \multirow{2}{*}{$\begin{array}{l}\mathbf{S} \\
\mathbf{N}\end{array}$} & \multirow{2}{*}{$\begin{array}{l}\text { Analysis } \\
\text { of } \\
\text { affected } \\
\text { area }\end{array}$} & \multicolumn{2}{|c|}{ Mean } & \multirow[t]{2}{*}{ Dif } & \multirow{2}{*}{$\begin{array}{l}\% \text { of } \\
\text { cha } \\
\text { nge }\end{array}$} & \multirow[t]{2}{*}{ SD } & \multirow[t]{2}{*}{ SE } & \multirow[t]{2}{*}{$\mathbf{t}$} & \multirow[t]{2}{*}{$\mathbf{P}$} \\
\hline & & BT & AT & & & & & & \\
\hline 1 & $\begin{array}{l}\text { Pigment } \\
\text { ation }\end{array}$ & $\begin{array}{l}16 . \\
07\end{array}$ & $\begin{array}{l}8.1 \\
3\end{array}$ & $\begin{array}{l}7.9 \\
3\end{array}$ & $\begin{array}{l}49.3 \\
8\end{array}$ & $\begin{array}{l}4.6 \\
2\end{array}$ & $\begin{array}{l}0 . \\
84\end{array}$ & $\begin{array}{l}9.4 \\
0\end{array}$ & $\begin{array}{l}<0.0 \\
01\end{array}$ \\
\hline 2 & $\begin{array}{l}\text { Oldest } \\
\text { Vitiligo } \\
\text { lesions }\end{array}$ & $\begin{array}{l}45 . \\
0\end{array}$ & $\begin{array}{l}26 . \\
27\end{array}$ & $\begin{array}{l}18 . \\
73\end{array}$ & $\begin{array}{l}41.6 \\
3\end{array}$ & $\begin{array}{l}9.1 \\
6\end{array}$ & $\begin{array}{l}1 . \\
67\end{array}$ & $\begin{array}{l}11 . \\
20\end{array}$ & $\begin{array}{l}<0.0 \\
01\end{array}$ \\
\hline
\end{tabular}




\begin{tabular}{|l|l|l|l|l|l|l|l|l|l|}
\hline 3 & $\begin{array}{l}\text { Newest } \\
\text { Vitiligo } \\
\text { lesions }\end{array}$ & $\begin{array}{l}13 . \\
23\end{array}$ & $\begin{array}{l}4.4 \\
0\end{array}$ & $\begin{array}{l}8.8 \\
3\end{array}$ & $\begin{array}{l}66.7 \\
5\end{array}$ & $\begin{array}{l}3.0 \\
3\end{array}$ & $\begin{array}{l}0 . \\
55\end{array}$ & $\begin{array}{l}15 . \\
07\end{array}$ & $\begin{array}{l}<0.0 \\
01\end{array}$ \\
\hline 4 & $\begin{array}{l}\text { Maximu } \\
\mathrm{m} \\
\text { Vitiligo } \\
\text { lesions }\end{array}$ & $\begin{array}{l}53 . \\
13\end{array}$ & $\begin{array}{l}27 . \\
70\end{array}$ & $\begin{array}{l}25 . \\
43\end{array}$ & $\begin{array}{l}47.8 \\
7\end{array}$ & $\begin{array}{l}11 . \\
73\end{array}$ & $\begin{array}{l}2 . \\
14\end{array}$ & $\begin{array}{l}11 . \\
88\end{array}$ & $\begin{array}{l}<0.0 \\
01\end{array}$ \\
\hline 5 & $\begin{array}{l}\text { Minimu } \\
\mathrm{m} \\
\text { Vitiligo } \\
\text { lesions }\end{array}$ & $\begin{array}{l}5.2 \\
0\end{array}$ & $\begin{array}{l}1.3 \\
3\end{array}$ & $\begin{array}{l}3.8 \\
7\end{array}$ & $\begin{array}{l}74.3 \\
6\end{array}$ & $\begin{array}{l}1.5 \\
0\end{array}$ & $\begin{array}{l}0 . \\
27\end{array}$ & $\begin{array}{l}14 . \\
10\end{array}$ & $\begin{array}{l}<0.0 \\
01\end{array}$ \\
\hline $\mathrm{N}=30$ & 30 & & & & & \\
\hline
\end{tabular}

\section{Group - B}

\begin{tabular}{|c|c|c|c|c|c|c|c|c|c|}
\hline \multirow{2}{*}{$\begin{array}{l}S \\
N\end{array}$} & \multirow{2}{*}{$\begin{array}{l}\text { Analysis } \\
\text { of } \\
\text { affected } \\
\text { area }\end{array}$} & \multicolumn{2}{|c|}{ Mean } & \multirow[t]{2}{*}{ Dif } & \multirow{2}{*}{$\begin{array}{l}\% \text { of } \\
\text { cha } \\
\text { nge }\end{array}$} & \multirow[t]{2}{*}{ SD } & \multirow[t]{2}{*}{ SE } & \multirow[t]{2}{*}{$t$} & \multirow[t]{2}{*}{$\mathbf{P}$} \\
\hline & & BT & AT & & & & & & \\
\hline 1 & $\begin{array}{l}\text { Pigment } \\
\text { ation }\end{array}$ & $\begin{array}{l}13 . \\
63\end{array}$ & $\begin{array}{l}6.6 \\
0\end{array}$ & $\begin{array}{l}7.0 \\
3\end{array}$ & $\begin{array}{l}51.5 \\
9\end{array}$ & $\begin{array}{l}4.1 \\
4\end{array}$ & $\begin{array}{l}0 . \\
76\end{array}$ & $\begin{array}{l}9.3 \\
1\end{array}$ & $\begin{array}{l}<0.0 \\
01\end{array}$ \\
\hline 2 & $\begin{array}{l}\text { Oldest } \\
\text { Vitiligo } \\
\text { lesions }\end{array}$ & $\begin{array}{l}56 . \\
73\end{array}$ & $\begin{array}{l}25 . \\
50\end{array}$ & $\begin{array}{l}31 . \\
23\end{array}$ & $\begin{array}{l}55.0 \\
5\end{array}$ & $\begin{array}{l}15 . \\
70\end{array}$ & $\begin{array}{l}2 . \\
87\end{array}$ & $\begin{array}{l}10 . \\
88\end{array}$ & $\begin{array}{l}<0.0 \\
01\end{array}$ \\
\hline 3 & $\begin{array}{l}\text { Newest } \\
\text { Vitiligo } \\
\text { lesions }\end{array}$ & $\begin{array}{l}13 . \\
07\end{array}$ & $\begin{array}{l}4.0 \\
0\end{array}$ & $\begin{array}{l}9.0 \\
7\end{array}$ & $\begin{array}{l}69.3 \\
9\end{array}$ & $\begin{array}{l}3.5 \\
9\end{array}$ & $\begin{array}{l}0 . \\
66\end{array}$ & $\begin{array}{l}13 . \\
83\end{array}$ & $\begin{array}{l}<0.0 \\
01\end{array}$ \\
\hline 4 & $\begin{array}{l}\text { Maximu } \\
\mathrm{m} \\
\text { Vitiligo } \\
\text { lesions }\end{array}$ & $\begin{array}{l}73 . \\
60\end{array}$ & $\begin{array}{l}34 . \\
97\end{array}$ & $\begin{array}{l}38 . \\
63\end{array}$ & $\begin{array}{l}52.4 \\
9\end{array}$ & $\begin{array}{l}20 . \\
52\end{array}$ & $\begin{array}{l}3 . \\
75\end{array}$ & $\begin{array}{l}10 . \\
31\end{array}$ & $\begin{array}{l}<0.0 \\
01\end{array}$ \\
\hline 5 & $\begin{array}{l}\text { Minimu } \\
\mathrm{m} \\
\text { Vitiligo } \\
\text { lesions }\end{array}$ & $\begin{array}{l}7.5 \\
3\end{array}$ & $\begin{array}{l}2.2 \\
0\end{array}$ & $\begin{array}{l}5.3 \\
3\end{array}$ & $\begin{array}{l}70.8 \\
0\end{array}$ & $\begin{array}{l}2.9 \\
2\end{array}$ & $\begin{array}{l}0 . \\
53\end{array}$ & $\begin{array}{l}10 . \\
02\end{array}$ & $\begin{array}{l}<0.0 \\
01\end{array}$ \\
\hline
\end{tabular}

\section{CONCLUSION}

Bhrajaka Pitta is causative factor for the normal and variations of the complexion of the skin. The deficiency of Bharajaka Pitta is one of the causative factor of the pathological conditions. On the basis of other clinical symptoms Shwitra Roga can be correlated with the vitiligo disease. Shwitra Kusthari Rasa and Shashilekha Vati both, medicine may activate the process of Pigmenttation in the presence of sunlight. Repigmentation was usually seen in periphereal region first and covering towards the centre from all directions. Taila are absorbed to be digested and utilized by body with the help of heat energy that is present in twacha as Bharajaka pitta. The heat energy present in the skin Bhrijaka Pitta Agni as per Ayurveda. At the same time according to modern science if excess heat from outside pentrates in the skin it lead to increase the melanocytic activity causing pigmentation and reduce elasticity of skin therefore skin is a good conductor of heat. Therefore it can be concluded that Shwitra Kusthari Rasa, Shashilekha Vati and Bakuchi Taila both are potent and effective for the management of Shwitra Roga vis-a-vis Vitiligo.

\section{REFERENCES}

1. Lorincz AL. Physiological and pathological chanes in skin from Sunbrun and suntan. JAMA. 196; 173.

2. Fitzpatrick TB. Dermatological differential diognosis. 1962.

3. Schwartz L, Tulipan L and Birminghan DJ, Occupation Disease of the skin. 3rd Ed. 1957.

4. WF Lever Histopathology of the skin. 4th Ed. 1967.

5. Schultze HE and Heremans JF. Molecular Biology of Human Proteins. Vol-li. 1996.

6. Parrish, Fitzzpattrick JA and Shea TB. Photochemotherapy of vitiligo. Use of orally administered proralen and highIntensity Longwave ultraviolet system Arch, Dermatol.1976; 112:1531-1534.

7. Kulkarni D. Anant and Mehar Chand Laxman Das. Ras Ratna Samuchcaya. New Delhi:

8. Tripathi Jagiswar. Chakradutta. Varanasi: Chaukhambha sanskrit office.

How to cite this article: Dr. Nand Kishor Dadhich. A physiological study of Bhrajaka Pitta and clinical view of Shwitra Kusthari Rasa and Shashilekha Vati in Shwitra Roga. J Ayurveda Integr Med Sci 2019;6:67-70. http://dx.doi.org/10.21760/jaims.4.6.12

Source of Support: Nil, Conflict of Interest: None declared. 